\title{
0 cenário esportivo como arena de disputas políticas: entre a memória recitada e 0 apagamento de rastros
}

\author{
The sports scene as a political dispute arena: between recited memory and \\ deletion of trails
La escena deportiva como arena de disputas políticas: entre la memoria recitada y la borradura de pistas

Cláudia Cristina da Silva Fontineles*

\begin{abstract}
Resumo: O presente texto discute em que medida dois elementos da vida esportiva do Piauí - o estádio de futebol "Albertão" e o time de futebol Tiradentes - foram tratados como acionadores na disputa entre os dois grupos políticos majoritários no cenário político piauiense, entre as décadas de 1970 e 1980. Tratados como insígnias do primeiro governo de Alberto Silva (1971-1975), foram aplaudidos por seus aliados como sinônimo da inscrição do estado em um contexto de prosperidade e da euforia desenvolvimentista, consonante com o cenário político em vigência no Brasil em tempos de Ditadura Civil-Militar, e rechaçados por seus oponentes por serem considerados a reafirmação da presença deste governo na história e na memória da sociedade piauiense. Neste artigo, discutimos como essas disputas manifestaram-se nas disputas políticas estabelecidas entre estes grupos e inscreveram-se no cotidiano e na memória social local. Para tanto, foram analisados como fontes históricas documentos oficiais, jornais de circulação no período, além das fotografias usadas pelo governo em suas correspondências oficiais e de relatos orais, que, à luz da interlocução teórica com Michel de Certeau, Réne Rémond, Paul Ricœur, Paul Veyne, Michel Pollak, entre outros, contribuíram para a elucidação analítica da temática.
\end{abstract}

Palavras-chave: História; Política; Esporte; Memória; Piauí.

\begin{abstract}
The present text discusses how two elements of sportive life from Piauí - the soccer stadium "Albertão" and the Tiradentes soccer team - were treated as triggers of the dispute between two majority political groups on te Piauiense political scene, during the 1970s and 1980s. They were treated as signs of the first government of Alberto Silva (1971-1975) andwere applauded by his allies as synonymous of inscription of the state in a context of prosperity and developmental euphoria, constant with the political scene in effect in Brazil in times of Civil Military Dictatorship, and they were rejected by his opponents for being considered the reassurance of presence of that government on history and memory of the Piauiense society. In this article, we discuss how such disputes manifested themselves on political wars established between those groups and signed themselves in the ways of political scene. Therefore, as historical sources, official documents, newspapers that circulated in that period were analyzed, besides the photos used by the government in its official letters and oral reports, that, under the theoretical interlocution with Michel de Certeau, Réne Rémond, Paul Ricœur and Paul Veyne, Michel Pollak, among others, contributed to the analytical elucidation of the theme.
\end{abstract}

Keywords: History; Policy; Sports; Memory; Piauí.

\footnotetext{
* Professora do Programa de Pós-Graduação em História do Brasil da Universidade Federal do Piauí (UFPI). Doutora em História pela Universidade Federal de Pernambuco (UFPE).

dados biográficos_biographic data
} 
Resumen: En este trabajo se analiza el grado en que dos elementos de la vida deportiva de Piauí - El estadio de fútbol "Albertão" y el equipo de fútbol Tiradentes - fueron tratados como accionadores en la disputa entre los dos principales grupos políticos en la escena política del Piauí entre las décadas de 1970 y 1980. Tratados como insignias del primer gobierno de Alberto Silva (1971-1975), fueron aplaudidos por sus aliados como sinónimo de inscripción del estado en el contexto de la prosperidad y la euforia del desarrollo, en consonancia con la escena política en vigor en Brasil en el tiempo de la Dictadura cívico-militar; y repelidos por sus oponentes, representando una reafirmación de la presencia de este gobierno en la historia y la memoria de la sociedad del Piauí. En este artículo, se discute cómo estas diferencias se manifestaron en las guerrillas políticas que se establecieron entre estos grupos y se afirmaron en la vida cotidiana y en la memoria social local. Por lo tanto, se analizaron como fuentes documentos oficiales históricos, los periódicos de la época, además de las fotografías utilizadas por el gobierno en su correspondencia oficial y las fuentes orales, que, a la luz del diálogo teórico con Michel de Certeau, René Remond, Paul Ricœur, Paul Veyne, Michel Pollak, entre otros, contribuyeron a la elucidación de análisis del tema.

Palabras-clave: Historia; Política; Deporte; Memoria; Piauí.

O 'simulacro'contemporâneo é, em suma, a localização derradeira do crer no ver, éo visto identificado com aquilo que se deve crer - uma vez que se abandonou a hipótese que esperava que as águas de um oceano invisivel (o Real) viessem habitar as margens do visivel e fazer delas os efeitos, os sinais decodificáveis ou os reflexos enganadores de sua presença.

(CERTEAU, 2004, p. 289)

\section{Introdução}

A principal façanha no combate à morte ou a seu correspondente - o esquecimento - catástrofe simbolizada pelo desaparecimento definitivo, é promovida pela associação da memória à retórica, uma vez que a citação e a recitação são instrumentos imprescindíveis na arte de fazer crer. Essa arte consiste em associar imagens a lugares, delineando um cenário arquitetural, e requer duas espécies de preceitos: os primeiros regendo a seleção dos lugares e os outros a das imagens mentais das coisas de que pretendemos nos lembrar e que a arte relaciona a lugares escolhidos. Por essa concepção, as imagens assim armazenadas são fáceis de evocar no momento oportuno, segundo o qual a ordem dos lugares preservaria a ordem das coisas, sendo que as 'coisas' figuradas pelas imagens e pelos lugares tratam-se de objetos, de personagens, de acontecimentos, de fatos relativos a uma causa a defender. Paul Ricœur salienta que "o importante é que essas ideias estejam vinculadas a imagens e que esses tempos sejam armazenados em lugares" (RICEUR, 2007, p. 76), e esses lugares, por sua vez, sejam portadores de significados. Discutir como as imagens relativas a eventos do cotidiano futebolístico (a inauguração do estádio de futebol "Albertão" e o funcionamento do time Tiradentes) foram tratadas como inscrições do primeiro governo de Alberto Silva na memória piauiense, ou foram combatidas por essa mesma razão, é o que pretendemos discutir neste texto.
Reencontra-se nessa leitura a metáfora da inscrição, com os lugares desempenhando o papel de uma tabuinha de cera, e as imagens, o das letras inscritas sobre elas, tendo a imaginação uma função determinante. A lembrança consistiria, assim, em efetuar saberes aprendidos, arrumados num espaço mental, não mais em evocar o passado. Essa seria uma "memória exercitada", conforme a interpretação de Ricœur, segundo o qual, a memória seria uma memória "cultivada, educada, esculpida" (RICEER, 2007, p. 77). A lembrança atualizada tenderia, portanto, a viver numa imagem. Daí a grande validade atribuída à imagem por aqueles que pretendem resistir ao tempo e inscrever-se na memória coletiva. Essa associação de imagens a lugares inscritos na geografia, que os gregos denominaram de "sítios da memória" e que Santo Agostinho chamou de "palácios" ou "armazéns" da memória continuam sendo construídos e ativados por meio do ato de recitar - tido como suporte da recordação (AGOSTINHO, 1996).

\section{Entre Polímnia e as águas do Lete}

A construção, preservação e evocação dos rastros marcam a história daqueles que pretendem inserirse no rol dos merecedores dos cantos de Polímnia. ${ }^{1}$

\footnotetext{
Polímnia, uma das filhas de Mnemósine, é considerada a musa dos hinos sagrados e da narração histórica.
} 
Alberto Silva tornou-se um dos amantes dessa musa, e como tal tratou de traçar percursos que lhe possibilitaram considerar-se merecedor desses cantos. Por meio da associação de imagens de lugares geográficos e simbólicos a seu nome procurou combater o desaparecimento, recusando-se a beber das águas do rio Lete - o rio do esquecimento - utilizando, para isso, a memória como grade de proteção. Na construção de seus palácios e sítios de memória cartografou também os sentimentos e reações da sociedade piauiense. Os ecos dessa memória foram requisitados em seu favor, mas nem sempre o que fora emitido lhe era favorável, ora transformando-se em elogios, ora em críticas. As decisões tomadas em seu primeiro governo na década de 1970 (1971-1975) o impeliram a reivindicar o título de fundador da modernização e da autoestima piauienses, repercutindo até entre seus adversários que de uma forma ou de outra sucumbiram a tal encanto em certo momento, reconhecendo seus feitos e iniciativas como importantes para o Piauí.

Respondendo às acusações elaboradas por seus críticos no início de seu primeiro governo, no ano de 1971, quanto ao fato de não ter sido capaz de construir uma imagem de seu governo que fosse acessível e apreciada pela sociedade piauiense como fora noticiado pelo jornal $A$ Hora, na edição de 8 de outubro de 1971 (A Hora, 1971), Alberto Silva transformou a luta pelo registro e pela manutenção de sua imagem na memória e na história locais o principal símbolo de sua luta contra o perecimento. As ações governamentais erigidas ainda nos anos 1970 funcionaram como verdadeiros palácios de memória e geraram aplausos e reconhecimento social, tornando-se os alvos privilegiados durante as recitações em defesa de seu nome ou mesmo quando contra ele voltava-se qualquer crítica. Suas obras integram quase todos os discursos em torno dos principais feitos administrativos já realizados no território piauiense. Relacionada a isso, a evocação de seus rastros continua sendo considerada merecedora de destaque na memória local. Daí a grande ênfase atribuída aos empreendimentos realizados por ele, seja para recitá-los ou para combatê-los, passando a funcionar como suas inscrições no tempo.

Os ares desenvolvimentistas, propostos como insígnias dos governos autoritários do período, no entanto, atingiram e seduziram o Piauí da década de 1970 e reverberaram nas décadas seguintes. Dessa forma, estudar essas intervenções no reordenamento espacial e infraestrutural do Piauí é mais uma oportunidade para percebermos a atuação efetiva de Alberto Silva como "engenheiro na política" no cenário local, haja vista que a atuação técnica era muito estimulada pelos governos e pelas manifestações históricas do período. Durante décadas esse caráter foi enfatizado, assim como os elementos de empreendedorismo que o notabilizaram junto à sociedade piauiense $\mathrm{e}$ brasileira, pois durante sua vida pública há constantes demonstrações de reverências e de admiração emitidas em relação à sua eminente capacidade técnica para explicar e sugerir propostas relativas a questões de seu ofício, seja na área da construção civil, seja na área dos transportes urbanos, nesses principalmente, dada a sua experiência à frente da Empresa Brasileiro de Transportes Urbanos - EBTU. Mais uma vez a associação de imagens a lugares serve para assegurar a continuidade temporal não só de uma pessoa, mas também de uma sociedade que autorizava sua existência e suas ações, fixando esses aplausos na passagem do tempo por meio da memória. Segundo Kevin Lynch, "a clareza da estrutura e a expressividade da identidade são os primeiros passos para o desenvolvimento de símbolos fortes" (LYNCH, 1999, 134).

Os rastros de Alberto Silva tornaram-se os rastros do que era validado socialmente no momento de suas ações, atravessando o tempo e inscrevendo-se na memória dos relatos construídos a respeito desse período. A atuação técnica era prestigiada no cenário político nacional em questão e isso repercutiu em sua trajetória pública. O governo de Emílio G. Médici valorizava em demasia o caráter técnico e nomeou políticos com este perfil para assumirem os governos estaduais durante seu comando político do país. Nesse governo, houve também forte aproximação, em nível nacional, entre política e futebol, a ponto de pesquisadores declararem que "Nunca futebol e política andaram tão de mãos dadas por aqui como nos anos que se seguiram ao tri de 1970" (MÁXIMO, 1999, p. 187).

No âmbito piauiense, a eficiência da propaganda sobre o nível de desenvolvimentismo atingido por seu governo nos anos 1970 foi tão aplaudido que reverberou no presente. Freitas Neto, um de seus mais combativos opositores, em texto publicado no jornal Diário do Povo, em 31 de agosto de 1997, reconhece que o desenvolvimento infraestrutural do Estado teve forte impulso a partir da década de 1970, esclarecendo que "só em 1971 o Estado teve sua universidade. Foi

\footnotetext{
2 Esta era a expressão pela qual Alberto Silva declarava gostar de ser reconhecido, como ele próprio declarara nos relatos orais prestados a esta pesquisadora.
} 
o último do Nordeste nessa corrida". Em seu texto, embora não mencione o nome do governador do Estado no período, declara que:

[...] deve-se, aliás, fazer justiça aos governos que se seguiram ao Golpe de 1964. Embora marcados pela concentração de renda, proporcionaram um grande avanço ao Piauí, especialmente no sistema viário e nas telecomunicações. Por exemplo, foi nessa época que se construiu a maior parte das rodovias cuja restauração hoje se impõe (FREITAS NETO, 1997).

Afirmações como essa confirmam a repercussão da imagem de prosperidade construída sobre esse governo, que nem sequer os adversários conseguiam ignorar, passando a reforçar sua presença na memória local. Essa inscrição na memória advém, conforme enuncia Paul Ricœur (RICCEUR, 2007, p. 72), da "ausência da coisa lembrada e sua presença na forma de representação".

\section{Futebol e disputas políticas: os signos da história e da memória}

No caso piauiense, essa representação se deu no cotidiano da população, tanto através do campo simbólico, quanto nos espaços físicos através da construção e da valorização dos vestígios materiais, associando representação e ação. A maior expressão disso foi a construção do principal e maior estádio de futebol do Estado, denominado de Estádio Governador Alberto Tavares Silva - o Albertão -, em homenagem explícita ao governador da época, em uma espécie de autoelogio, que ensejava a inscrição de si na memória e na história do Piauí como forma de combater os riscos do esquecimento. E pelo que se pode observar em depoimentos como o de dona Genu Moraes, ele conseguiu seu intento, pois quando perguntada sobre o que mais destacava nas gestões desse governador, logo ressalta a construção desse estádio de futebol "ele, no primeiro governo dele, ele conseguiu muita coisa como construir o Albertão e outras obras" (MORAES, 2008, s./p.). O destaque à construção do Albertão indica como essa obra, dentre tantas, inscreveu o nome de seu construtor na lembrança da sociedade, pois em toda oportunidade em que se menciona obras piauienses de grandes dimensões e importância, o Albertão está incluso, assim como ocorre com a quase totalidade das construções arquitetônicas realizadas no primeiro mandato. A decisão em construir essa obra, além de estar em consonância com os valores pregados no período no país, que vivia sob a égide da publicidade da suposta euforia econômica, contribuiu bastante para registrar o nome de seu idealizador, tornando-se um de seus "palácios da memória".

Inaugurado em 26 de agosto de 1973, esse estádio traz consigo demonstrações da força que o inusitado tem na história, evidenciando como é possível por ela se enamorar e se envolver, ao mesmo tempo em que a seduz e a enreda em seus encantos. Mais uma vez os ensinamentos de Paul Veyne (1998), ao discorrer sobre a importância do acaso para a história, são merecedores de consideração. $O$ festivo e o fúnebre fazem do cenário piauiense o palco de seus enlaces. $\mathrm{O}$ que era para ser uma das principais festas de comemoração aos empreendimentos do governo albertista e de seus apoiadores autoritários, tornou-se o palco de uma tragédia, pois aos vinte e seis minutos do primeiro tempo do jogo inaugural iniciou-se um tumulto gerado pelo alarde falso de que o estádio desabaria provocado por um barulho no começo da partida. Embora a denúncia não tenha sido confirmada, acabou gerando uma forte confusão que ceifou vidas e deixou o saldo de muitos feridos. Segundo Zózimo Tavares, "oficialmente, houve o registro de oito mortos, mas acredita-se que esse número foi bem maior. Centenas de pessoas ficaram feridas" (TAVARES, 2000, p. 92).

Tida como uma das obras-símbolo da prosperidade dos governos federal e estadual, que tornaria o Piauí merecedor de sediar até jogos da seleção brasileira, equipe tão cortejada e aplaudida no período, considerada a expressão maior do progresso vivido no país e alavanca da empreitada de construção da autoestima da população local, o Albertão foi palco de uma grande festa que sediou o jogo do time carioca Fluminense contra o time piauiense do Tiradentes - visto no campo futebolístico como baluarte do progresso desportivo que tanto era alardeado pelo governo. Por meio do Albertão prestigiar-se-iam dois símbolos do ideal de progresso difundido na época: um empreendimento arquitetônico de grande porte e o futebol - esporte que causava euforia na sociedade e era tratado intencional e erroneamente como um dos emblemas dos governos militares em todas as campanhas publicitárias (AGOSTINHO, 2002; CALDAS, 1994 RIBEIRO, 2003). A atuação desse time piauiense tornou-se de tal forma símbolo da ação de Alberto Silva que seus rivais, ao assumirem o governo em sua sucessão, passaram a tê-lo como alvo de combate e propuseram desestruturar essa equipe para minar qualquer influência do exgovernador sobre a população piauiense, por ser visto 
como uma das insígnias da prosperidade atribuída a esse governo.

José Lopes dos Santos (1982) ratifica tal informação. Ao analisar os mecanismos utilizados para combater a imagem do ex-governador, em meados da década de 1970, ele esclarece que foram sugeridas ao governador Dirceu Arcoverde - sucessor de Silva algumas estratégias de interdições às reminiscências da liderança de seu antecessor na vida do Estado, devendo ser evitada até sua influência na área desportiva, que era simbolizada principalmente pelas atuações do time do Tiradentes em campeonatos e partidas de futebol. Os caminhos propostos a serem tomados para sua eliminação no cenário desportivo eram os seguintes:

No setor esportivo, para a formação de boa imagem junto aos desportistas, o Governo não pode fazer incursões com medo e desconfiança. A volta do Tiradentes, sob qualquer pretexto, será um desastre. O surgimento de um River forte com a direção atual é desaconselhável. A única opção será o Esporte Clube Flamengo, que passaria a ter apoio total do Governo e de grupos empresariais a ele ligados visando à arrecadação de recursos financeiros expressivos e indispensáveis para a formação de uma grande esquadra que possibilitasse a classificação no Campeonato Nacional. Não há outra maneira de esquecer o Tiradentes, mesmo que ele seja sepultado, em definitivo (SANTOS, 1982, p. 134 - grifos nossos).

Como se vê, os ressentimentos em relação à condução administrativa do Piauí e aos caminhos traçados pela memória coletiva não pouparam nem sequer o setor esportivo, promovendo suas "revisões" (ANSART, 2001, p. 32). Era necessário impedir que qualquer elemento que se relacionasse ao primeiro governo albertista prosperasse, sendo proposta inclusive sua erradicação. Dessa forma, relegar o time Tiradentes ao esquecimento, um dos símbolos dos empreendimentos do governo de Silva, era ameaçá-lo também de "esquecimento por apagamento de rastros", para utilizar uma expressão cara à análise de Ricœur (2007, p. 425). À medida que se propunha, ao mesmo tempo, o apoio total ao time do Flamengo local e a supressão de qualquer aliança com o River, que era administrado por oponentes, sugeria-se que se "sepultasse" definitivamente qualquer resquício do prestígio gozado pelo time do Tiradentes.

$\mathrm{Na}$ oportunidade em que se via ameaçado pelas lembranças referentes ao time, pretendia-se também aniquilar o governo a ele relacionado e todas as ações que pudessem atribuir-lhe aplausos, tentando promover um esquecimento orientado. Segundo essa proposta, os "sítios" da memória construídos pelo governo albertista não poderiam prosperar, nem tampouco ser visitados, uma vez que se propunha que fossem extintos ou silenciados. Seus opositores visavam à sua invisibilidade e a seu silenciamento através do apagamento dos vestígios e sinais deixados pelo exgovernador na memória piauiense. Essa disputa dava realce às divergências existentes na ARENA, pois ambos os governadores - Alberto Silva e Dirceu Arcoverde - eram filiados a este partido - o primeiro à ARENA 2 e o segundo à ARENA 1.

Não bastava o tempo para suplantar as ações albertistas, eram necessárias medidas que colaborassem com esse apagamento de rastros, por isso se informava que "a volta do Tiradentes" seria "um desastre" dada sua estreita relação com a imagem do governadorengenheiro. Daí a ênfase aos mecanismos empreendidos para promover seu "sepultamento".

Essa tentativa de pulverizar os registros deixados por Alberto Silva na história piauiense está associada ao reconhecimento de que os modos de durar necessitam apoiar-se num suporte material, numa apresentação figurada, pois a coisa retratada apresenta identificação com a representação que dela é feita, funcionando como a madeleine em Proust, que possibilitava ao herói de sua obra Recherche manter o vínculo com Combray. A memória, mediando a contradição entre a sobrevivência e o nada, insere-e como colaboradora na tradução dos hieróglifos deixados pelo tempo, pois conforme esclarece Gilles Deleuze, "as essências são, ao mesmo tempo, a coisa a traduzir e a própria tradução; o signo e o sentido"(DELEUZE, 2006, p. 95). Hieróglifos não têm faltado a essa narrativa histórica repleta de registros a serem decifrados pelos intérpretes do tempo, num constante desafio da história-esfinge que nos desafia a todo instante.

Assim, as lembranças tendem a ser atualizadas por meio das imagens, que funcionam como notas de memória, balizando os caminhos percorridos. O estádio Albertão tornou-se um desses espaços de evocação dos rastros do político que lhe emprestou o nome, seja como espaço físico, seja pela denominação recebida, que provoca o tempo presente, lembrando-o constantemente do homenageado e funcionando como arquivo dessa memória, uma vez que os monumentos que constituem o patrimônio arquitetônico funcionam como verdadeiros "lugares da memória", no dizer de Pierre Nora (2006, p. 7-9). Esses lugares visam 
a promover uma adesão afetiva entre o grupo que compartilha a memória comum representada por tais símbolos físicos, mas principalmente visam atualizar a presença do homenageado no tempo. Esse estádio, inclusive, é uma das obras mais destacadas entre os simpatizantes de Silva como um dos principais empreendimentos arquitetônicos já construídos no Piauí. Entre seus críticos, no entanto, é considerada como uma das eminentes representações do faraonismo promovido com os recursos públicos, sendo constantemente referido como exemplo maior do desperdício do dinheiro público no ápice do projeto desenvolvimentista vigente na ocasião, embora predominem as posturas apreciativas.

Esse estádio passou a funcionar como parâmetro para mensurar a popularidade de Silva no cotidiano da população do Estado. Todas as vezes que ele ou seus aliados referiam-se ao apoio recebido da população, mencionavam o fato de ele ser o único político capaz de lotar o Albertão e de ser ovacionado por todos os presentes. Referindo-se a isso, um dos mais ferrenhos aliados de Silva - Tomaz Teixeira - confirma que "o Albertão passou a ser um lugar de testes de popularidade. A oligarquia não ignorava que ali estava o principal reduto de aplausos do ex-governador" (TEIXEIRA, 1981, p. 81-82). Esse assessor informa que todas as vezes que Silva comparecia ao estádio era aplaudido de pé pela população, e que isso ocorria como uma forma de agradecimento pela construção do "magnífico estádio e por ter colocado o Piauí no Campeonato Nacional, além de ser reconhecido como estadista e líder popular" (1981, p.84). Conforme sua narrativa, esse reconhecimento era suficiente para despertar a proibição da divulgação do nome do político parnaibano no sistema de som do estádio e até nas rádios que transmitiam os jogos durante os mandatos de seus adversários.

Como resposta a tal censura, de acordo com Teixeira, seus aliados utilizavam como subterfúgio soltar um foguetão para avisar à população da presença do ex-governador. Esse estádio, decididamente, tornara-se o palco de disputas não apenas desportivas, mas principalmente de cunho político e era encarado como uma arena de embates entre os grupos políticos rivais, porque nele se passaram alguns importantes conflitos da história recente piauiense, principalmente porque ele expressava uma luta velada pelos comandos do Estado, como evidenciou o próprio Tomaz Teixeira ao se referir aos aplausos obtidos no Albertão no início da década de 1980 como mudança de rumo no comando político do Piauí: "Os intensos aplausos na praça esportiva era o prenúncio de que a oligarquia começava a perder terreno. Os piauienses haviam escolhido novo comandante" (1981, p. 84). Em mais essa oportunidade evidenciavam-se as disputas em torno da liderança política do Estado. Daí a validade dos estudos sobre política para o entendimento da história, como enuncia René Rémond de que "o político não constitui um setor separado: é uma modalidade da prática social" (1996, p. 35-36).

As lutas em torno do significado do estádio surgiram antes mesmo de sua construção, sendo considerada pelos correligionários do governador a marca da introdução do Piauí em um outro tempo, um tempo de conquistas e de realizações modernas. Segundo seu idealizador e construtor, o Albertão foi mais uma resposta de seu governo à provocação feita em relação à inserção do Piauí na modernidade por meio do êxito representado pelo desempenho futebolístico do Brasil na época. Basta lembrar que este é o período marcado pela euforia da conquista do tricampeonato mundial de futebol pela Seleção Brasileira, no México, em 1970, que foi amplamente utilizado pelo Regime Autoritário em vigência no país, como símbolo-mor das gestões militares, naquilo que Carlos Eduardo Sarmento enunciou como: "catarse coletiva", que teria sido "largamente manipulada para que se transformasse em um patriotismo servil, com a vitória em campo associada a uma conquista do regime militar" (SARMENTO, 2006, p. 129).

Esse mesmo autor declara que, dado o potencial que o futebol apresentava para mobilizar as massas, o Regime Militar dedicou especial atenção a seu desenvolvimento e criou órgãos responsáveis por tratar apenas de questões que lhe estivessem associadas, cujo propósito, entre outras coisas, era o de fazer ilações entre este esporte e o projeto nacional-desenvolvimentista difundido pelos militares, no esteio do que era proposto desde o governo de Juscelino Kubitschek, em direta confluência com o projeto "Brasil ame-o ou deixe-o" (SARMENTO, 2013).

No cenário piauiense, a construção do Albertão foi utilizada como um elemento difusor da imagem de Alberto Silva como o governador-torcedor, no esteio do que Emílio Garrastazu Médici fizera ao se projetar publicamente como o "presidente-torcedor" (CHAIM, 2014, p. 70), ao mesmo tempo que o estádio serviu como o aglutinador que promoveria a identificação da população com seu Estado, por meio de mais esse símbolo da introdução do Piauí nos moldes de modernidade e progresso difundidos no período: 
[...] fizemos um estádio porque me procuraram e me disseram "Governador, o Piauí é o único Estado que não pertence, não participa do campeonato nacional". Aí eu disse: "Por quê? É por que não tem estádio?”. E na época, do tri do Pelé, no auge com seus companheiros, Marco Antonio e toda aquela turma da seleção de 70, né, que era aquele hino, que empolgava todo mundo, o Piauí também tava empolgado, queria um estádio, e aí, muito bem, então vamos fazer um estádio. Comuniquei ao presidente Médici. Eu disse que queria um estádio e ele disse "Você tem dinheiro lá, então tá certo, então é com o senhor", "E eu vou fazer um estádio, extremamente econômico, o senhor vai ver". Aí nós começamos a trabalhar no estádio, a trabalhar nas bases, no campo de futebol, etc..., e eu tava convencido que a CBD, naquele tempo o João Havelange era o dirigente, ele não nos daria a autorização pro Piauí entrar no campeonato nacional. Um dia, lembro bem a data, 21 de abril, o João Havelange ligou pra mim e disse: "Governador, nós fizemos um estudo aqui, o Piauí vai entrar no campeonato nacional". Eu disse: "Não me diga!". Aí eu disse ao João Havelange: "Quando é que vai ser o primeiro jogo?", "Dia 26 de agosto". Eu disse: "Faltam menos de 180 dias e o que é que eu preciso fazer?", "Só o estádio", eu digo: “De quanto?", "No mínimo de 40.000 lugares.” (SILVA, 2006, s./p.).

O ex-governador assume novamente a postura de condutor do Piauí na marcha desenvolvimentista rumo à flecha do progresso lançada sobre a sociedade brasileira no período, como se isso significasse um desafio inadiável ao qual todos deveriam atender. O progresso agora calçava chuteiras e circulava dentro de um campo de futebol à procura de uma bola, de preferência ornado com gigantescos contornos de concreto e de refletores, a roupagem predileta de quem pretendia o título de símbolo do desenvolvimento. O caráter empreendedor da fala não se esgota no fato de construir um estádio, mas em quais condições isso estava circunscrito, pois era uma resposta a uma provocação ao fato de o Estado não estar inserido no campeonato nacional por não possuir um estádio que comportasse jogos desse porte. Novamente os custos dessa obra passaram pelo crivo e aprovação dos governos militares, como salienta o relato, pondo em relevo mais uma vez o caráter centralizador com que a administração nacional conduzia os feitos dos governadores nomeados por ela, o que demonstra também que as ações do governo estadual não ocorriam à revelia do conhecimento de Brasília. Mas, por meio desse depoimento, também é possível notar a consonância entre as propostas local e nacional, cujo fruto era a liberação e inauguração da obra. Tanto é que essa construção passou a ser a insígnia maior de sua administração, sendo registrada em diferentes arquivos, entre os quais destacam-se os registros visuais da atuação do governador, que passaram a atuar como verdadeiros cartões-postais de seu mandato, como a que segue:

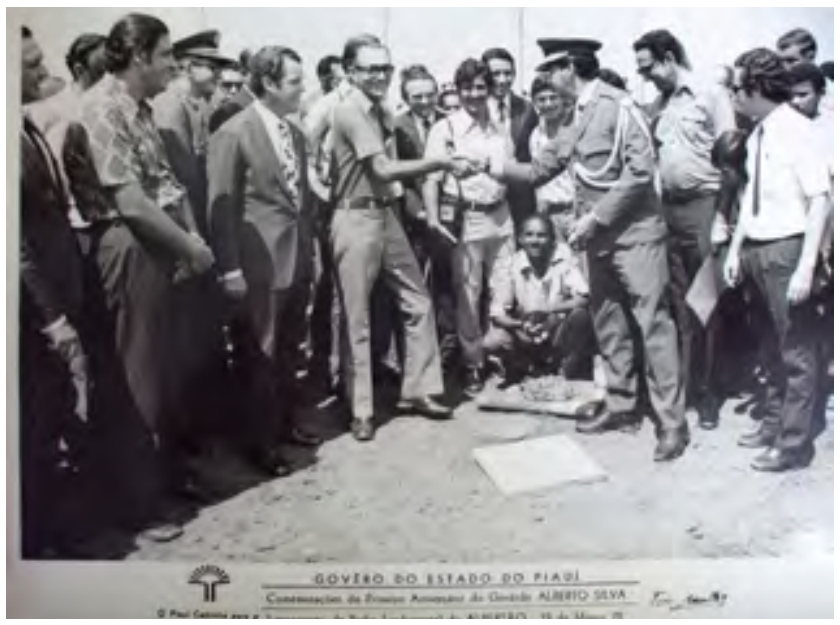

Foto 1. Lançamento da pedra fundamental do Albertão. 13 de março de 1972.

(Fonte: Arquivo Público do Estado do Piauí - Casa Anísio Brito)

O caráter apoteótico do feito, portanto, foi acentuado no relato de Silva em decorrência da exiguidade do tempo e das dimensões exigidas à obra. A partir do aval positivo para a construção desse espaço desportivo, o governador passou a registrar com textos e imagens todas as etapas. A fotografia anterior, por exemplo, é alusiva ao lançamento da pedra fundamental desse estádio, ocorrido em 13 de março de 1972 e mostra um sorridente governador, cercado de autoridades e de simpatizantes, posando durante um cumprimento efusivo a um dos militares envolvidos no projeto. Não bastasse a identificação visual do governo com o evento por meio da produção de uma fotografia, ele providenciou criar as legendas impressas na fotografia que impediam qualquer dúvida quanto à sua autoria. Essa produção imagética recebeu a identificação do símbolo oficial do governo e foi difundida em órgãos públicos e privados, permitindo, por meio da fotografia, manter viva a imagem fugidia daquele instante de vida que fluía, ativando a memória sobre ele, ao tentar preservar "aquele fragmento congelado da realidade" (KOSSOY, 2001, p. 156). ${ }^{3}$

\footnotetext{
3 Nesta obra, o autor informa que os personagens retratados, os cenários e os autores-fotógrafos e seus equipamentos desaparecem, mas a fotografia sobrevive enquanto for conservada.
} 
Junto à expectativa de possuir um grande estádio de futebol, essa obra provocou euforia quanto aos empregos que geraria, pois sua construção envolveu grande número de operários, como esclarece Alberto Silva:

Colocamos lá 3.500 homens, 2.000 cozinheiras, para trabalhar dia e noite, estabeleci um regime, como no tempo do Regime não tinha esses tipos de exigências que têm hoje, em termos de leis trabalhistas, eu fiz muito melhor que o Ministério do Trabalho faz. Eu disse pros operários que iam trabalhar naquele estádio, iam comer por conta das empresas, e não trabalhavam oito horas seguidas, trabalhavam menos, se alimentavam e iam descansar, e depois voltavam. Duvido que as leis trabalhistas de hoje façam algo melhor do que isso, os operários vibraram, porque não eram oito horas de trabalho, eram só seis. Se alimentavam e iam descansar e se revezavam de 48 em 48 horas. Por isso eu tive o apoio total da classe dos trabalhadores, e os engenheiros também, e fizemos o estádio, e no dia 26 de agosto, o Fluminense jogou nele aqui, com Globo, com todo mundo presente (SILVA, 2006, s./p.).

Por esse relato podemos perceber um pouco do cotidiano dos operários que trabalhavam na construção desse estádio, permitindo vislumbrar algumas características na maneira de tratar esses trabalhadores numa época em que "não tinha esses tipos de exigências que tem hoje, em termos de leis trabalhistas", reconhecendo que esse grupo trabalhava diuturnamente para cumprir o calendário estipulado a fim de inserir o futebol piauiense no campeonato nacional e, por sua vez, inserir o Piaú no projeto de modernidade semeado no período - a grande meta a ser atingida. $\mathrm{O}$ apoio conquistado junto aos empregados da construção civil deveu-se também pelo número de empregos que esse setor gerou, como declarou Dona Maria Isaura, que informou que nesse período cinco dos seus filhos encaminharam-se de Parnaíba para Teresina, todos absorvidos pela construção civil, que empregava muita gente. Ela relatou que "[...] era certo vim pra Teresina e conseguir emprego. Meus filhos todos encontraram, trabalhavam muito, mas tiveram emprego nas construções do Seu Alberto" (FONTINELES, 2004, s./p.). ${ }^{4}$

$4 \mathrm{Na}$ época da entrevista, a costureira parnaibana e dona de casa tinha oitenta e cinco anos.

\section{Albertão: a vitória da narrativa eufórica sobre a dor}

No esteio do projeto de integração nacional e da euforia gerada pela conquista do tricampeonato mundial de futebol, a construção de um estádio de futebol nos moldes dos construídos em outros grandes centros passou a representar um dos desafios ao governo da época por ser um dos atributos exigidos para integrar o rol dos Estados considerados modernos. A partir da comunicação de sua construção, os jornais passaram a acompanhar todos os lances dessa nova trama e, junto com o governo, cronometravam as etapas da obra, além de contribuir para temperar tal expectativa com uma série de capítulos. Diariamente os periódicos traziam em suas páginas novos elementos dessa composição. Eram comuns manchetes de primeira página destacando novos componentes dessa intriga, como a publicada no dia cinco de outubro de 1971 pelo jornal A Hora, que evidenciava a vinda do jogador Tostão - campeão mundial em 1970 - para o jogo inaugural do estádio.

A repercussão social causada pela possibilidade da presença do tricampeão mundial de futebol era apenas mais um ingrediente da apologia à inauguração desse estádio, tempero este que acentuava ainda mais a euforia gerada pela construção daquilo que passou a ser chamado de o templo do futebol piauiense. Era tamanha tal expectativa que o próprio governador decidiu temperá-la ainda mais com a cobrança de um pênalti durante sua inauguração. A cobrança ocorreu sem que houvesse goleiro no gol, tendo um desfecho favorável ao cobrador, tanto em suas aspirações futebolísticas quanto políticas, pois, conforme sua descrição, essa cobrança foi mais uma oportunidade para ele ser aplaudido pelo público de setenta mil pessoas que lotava o estádio para assistir ao jogo e contemplar mais essa obra de seu governo. O novo palácio da memória já se erigira e com ele mais oportunidades de promover seu construtor.

Mais um "gol de placa" era marcado pelo então governador e dessa vez a linguagem denotativa cedia espaço para a linguagem conotativa em suas dimensões políticas, pois não faltaram placas para registrar o evento, senão o gol, tudo o que ele implicava e simbolizava: as realizações arquitetônicas de um governo que pretendia gravar seu nome na história e na memória do Piauí. E para tanto recorria a todos os instrumentos possíveis, fazendo de seus aparecimentos públicos momentos oportunos para inscrever-se na memória de sua gente, como fez com esse evento, que foi vastamente registrado por fotografias. A 
cobrança dessa penalidade máxima sem a presença de um goleiro, por exemplo, foi retratada enfatizando a imagem do cobrador e omitindo as circunstâncias da cobrança, nem sequer as traves aparecem na imagem, para que o caráter épico da inauguração não fosse maculado pelo fato de a cobrança não dispor de uma resistência de um defensor no gol. Em mais essa oportunidade, os registros imagéticos do administrador ganhavam prioridade, atribuindo-se "às coisas reais as qualidades de uma imagem" (SONTAG, 1986, p.139-140), diferentemente do que se supunha anteriormente quanto à eficácia das imagens, quando se presumia que as imagens possuíam as qualidades das coisas reais.

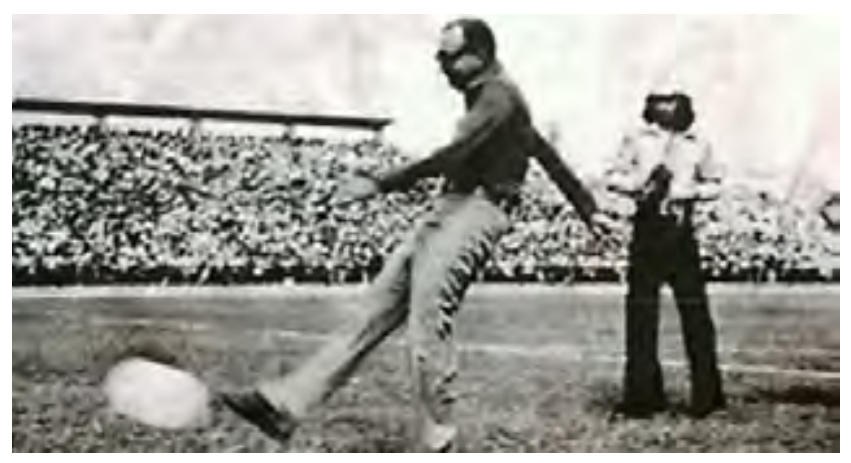

Foto 2. Cobrança de pênalti no jogo inaugural do Estádio Governador Alberto Silva (Albertão).

(Fonte: Arquivo Público do Estado do Piauí - Casa Anísio Brito)

Assistia-se a mais um empreendimento desse governador que preferia ser reconhecido por seus conhecimentos técnicos de engenheiro, mas que também passara a atuar como artilheiro nas horas vagas, aproximando-se do esporte de maior aprovação no seio social brasileiro. Tornar-se ídolo, não no futebol, mas na política, seria, portanto, seu grande desejo com esse empreendimento e era preciso que esse evento ficasse registrado das mais diferentes maneiras possíveis. Dadas as possibilidades que a câmera fotográfica dispõe para a realidade se apresentar, ela foi eleita como um dos instrumentos privilegiados para a conservação e propagação dos feitos albertistas, registrando tanto o evento focado em suas lentes, quanto as intencionalidades contidas no testemunho histórico exposto nas formas iconográficas, sobretudo pela perspectiva adotada por sua lente ao retratar o chute do governador.

Os registros fotográficos encontrados sobre esse evento priorizaram a imagem do governador em detrimento da dos desportistas envolvidos na partida como se pretendessem "embalsamar frações" (BORGES, 2008, p. 39) desse momento. Nessa fotografia da cobrança do primeiro gol no Albertão não aparece menção aos times que disputavam a partida, o foco era seu cobrador, a quem se queria aplaudir e atribuir essa realização, contemplada como necessária para inscrição do Piauí no espírito esportivo de então, em que o futebol era tratado como elemento de propagação do orgulho nacional.

Tratando da ausência de goleiro durante a cobrança, posteriormente, Silva a justifica como fruto de uma decisão para amenizar exigências sobre si e sobre o guarda-metas. Assim, ele não receberia pressão quanto à facilitação ou não da defesa. A cena dessa cobrança funciona quase como uma metáfora de como um governante preferiria governar: sem resistências e sem obstruções, o que facilitaria a realização de seus objetivos, sobretudo se após sua conclusão fosse consagrado como um craque naquilo que fazia.

Embora os relatos que tratam da inauguração desse estádio tenham enfatizado o confronto entre o time carioca do Fluminense e o Tiradentes do Piauí, nesse plantel havia apenas dois jogadores piauienses, os demais foram contratados de times do Rio de Janeiro, a pedido do governador piauiense, pois, de acordo com seu depoimento, jogadores bons só havia dois, "o goleiro que é muito bom, e tem o Sima que é um craque", permitindo notar que não apenas o estádio de futebol fora construído para essa partida, mas o time que representaria o Piauí também. Isso expressa bem o grau de preocupação com a aprovação coletiva daquele instante sacralizador da história piauiense, que expressava em si muitos dos desejos de durar de quem o propunha. Isso muito se assemelha àquilo que Hilário Franco Jr. Define como uma metáfora religiosa ao tratá-lo como "dança dos deuses", uma expressão cara nas crônicas de Nelson Rodrigues, que assumiu o caráter simbólico no texto desse historiador. Segundo ele, os estádios tornam-se templos sagrados e sacralizados socialmente e até mesmo os uniformes dos times passaram a ser denominados de "mantos sagrados" e "Em torno a cada divindade futebolística desenvolve-se uma seita" (FRANCO JR. 2007, p. 263). Durante a década de 1970, inserido na euforia nacional gerada pela conquista do tricampeonato mundial de futebol, Alberto Silva pretendia partilhar deste clima sacralizado usufruído por esse esporte.

Não bastava construir o estádio, nem inserir o futebol piauiense no campeonato nacional, era mister fazer tudo isso e ainda participar de forma competitiva, para evidenciar o valor do povo piauiense, nem que para isso se tivesse que contar com a participação 
de muitos jogadores de outros Estados brasileiros, contratados especificamente para contribuir com esse propósito.

O fascínio com a obra construída e com o olhar exterior voltado para o Piauí, contudo, não foi suficiente para conter a tragédia que acompanhou a inauguração em virtude do acidente que lá ocorreu. Mesmo isso não abalou a maneira gloriosa com que a apreensão desse acontecimento foi requerida no relato do exgovernador, pois reconhece que houve um acidente gerado a partir de um alarde falso de que o estádio estava desabando em razão do barulho provocado por um avião sobrevoando esse espaço desportivo, disso gerando um pânico geral, do qual derivaram vários mortos. Todavia, esclarece que os danos só não foram maiores em virtude da solidariedade pulsante da sociedade teresinense que atendeu prontamente a seu apelo por ajuda, transmitido ao vivo pela televisão que seu governo ajudara a fundar, erigindo novamente seus "lugares de memória" e revelando mais uma contribuição de seu governo para modernizar o Piauí, como ele próprio narra:

Por causa de um barulho de avião que passou, alguém gritou que o estádio estava caindo, foi horrível, mas é, foi doloroso, porque no final mesmo assim houve alguns mortos e foi horrível aquele negócio, mas eu parei e eu fiz um apelo, que entre as coisas que eu fiz pelo Piauí, eu mandei financiar a televisão, talvez uma das primeiras, seguramente a primeira televisão colorida, a tevê canal 4, era um sonho do Valter Alencar, e ele foi me pedir para eu realizar esse sonho e me trouxe um projeto de uma televisão preto e branco. Eu disse: "Nesse governo não se faz televisão preto e branco, vai ser colorida". Era uma novidade no país, mas aqui a nossa foi colorida e ela estava lá no campo junto com a Globo, com todo mundo, a também rádio do Piauí, também a tevê rádio Clube estava lá filmando. Eu fiz um apelo pelo microfone dela, falei que corressem ao estádio médicos, enfermeiros e tudo, e como o estádio tinha uma entrada que poucos estádios têm dos dois lados, entraram ambulâncias pelos dois lados e os próprios jogadores, e todos os enfermeiros e médicos dessa cidade correram pra lá, socorreram mais de 300 pessoas, e depois que clamo aquilo, em meia hora tava todo mundo hospitalizado, infelizmente teve mortos e feridos, foi uma fatalidade. João Havelange, sentado do meu lado, eu perguntei, "E agora?”, “Toca o jogo". Aí eu mandei abrir os portões, e entrou mais gente, mais gente, e o jogo ficou empate, mas foi uma loucura o povo foi ao delírio, o time do Piauí empatar com o Fluminense aqui dentro, foi um delírio (SILVA, 2006, s./p.)

O relato mescla dor, compaixão e solidariedade à euforia e entusiasmo, sem ignorar, em momento algum, o desejo pelo reconhecimento dos feitos relativos ao incentivo à implantação de uma emissora de televisão no Piauí, destacando o fato de sua originalidade em ser colorida. Embora seu idealizador tivesse apresentado um projeto preto e branco, era necessário ir além do desejado se isso implicasse em demonstrar arrojo e determinação. $\mathrm{O}$ desejo por ser reconhecido não pela tragédia, mas pelo empreendedorismo do momento, salientando mais suas conquistas que as dificuldades derivadas do acidente, mostram a significativa ambivalência que permeia a narrativa quanto a esse acontecimento. Ao dar prioridade à iniciativa de ter financiado a implantação de uma rede de televisão colorida em solo piauiense, destaca mais uma decisão de seu governo no sentido de inserir o Piauí nos projetos modernos. A televisão colorida seria mais um dos sinais dessa inclusão, atuando como um dos símbolos dessa aspiração moderna, tendo funcionado ainda como porta-voz do pedido de auxílio emitido pelo governo para socorrer as vítimas do acidente, uma invenção moderna proporcionada por seu governo, colaborando para que a outra não fosse aniquilada pela tragédia que nela ocorrera.

Essa porta-voz foi mais evidenciada que o próprio evento no qual se propunha intervir, talvez na tentativa de minimizar seus danos. Os holofotes da transmissão pareciam mais voltados para os espaços de concreto que para o sangue derramado e a dor sentida pelas vítimas, afinal, sob essa perspectiva, o evento deveria ser a oportunidade de contemplação de um feito magnífico da arquitetura e da engenharia locais, não podendo ceder espaço para qualquer elemento que comprometesse seu brilho: mortes, por exemplo.

Isso é denotado nas coberturas jornalísticas do período, que enfatizaram as virtudes da inauguração em detrimento dos registros sobre o acidente. Mesmo quando tratou do acidente, a imprensa local priorizou a magnitude e a segurança da obra em prejuízo do detalhamento sobre a tragédia. A matéria jornalística do dia 28 de agosto de 1973, por exemplo, ao se referir ao acidente, acentuou a firmeza e qualidade da obra arquitetônica construída, publicando declarações do governador nas quais ele negava qualquer abalo 
na estrutura da construção, além de destacar que "o estádio nada sofreu, pois é uma obra sólida e construída dentro de modernas técnicas". E, assumindo a defesa da engenharia local, informou que:

[...] foi um fato isolado e que ao nosso entender, qualquer insinuação que procure atribuir à construção civil piauiense o menor sentido de culpa pelos fatos lamentáveis do Albertão será sempre uma encomenda injusta e leviana que não poderá, portanto, receber o crédito da população ( $O$ Dia, 1973 , p. 1).

O momento deveria ser celebrativo, não fúnebre, embora a eventualidade do acidente tenha encaminhado a inauguração para essa direção. Alberto Silva pretendia ser lembrado não pela tragédia, mas pelos investimentos na inovação de diferentes setores da administração estadual e isso era confirmado pelas coberturas jornalísticas desse evento. $\mathrm{O}$ palco da memória não poderia ser maculado, daí a ênfase aos elementos positivos conquistados nessa inauguração, como a qualidade técnica da construção civil e da arquitetura locais - logo defendidas como mais um patrimônio piauiense que deveria ser livrado de qualquer imbricação com o acidente em questão - e a transmissão ao vivo e em cores por uma rede de televisão do Piauí. Mesmo reconhecendo a gravidade desse acidente, seus relatos a respeito destacam os aspectos positivos da inauguração, atenuando, dessa forma, os efeitos da tragédia sobre a imagem de seu governo. Esses relatos muito se assemelham aos feitos pelo presidente da República em suas aparições públicas, como durante a inauguração do estádio do Morumbi, em 1970, no qual Médici enfatizou as contribuições de seu governo para a transmissão pela televisão em cores da Copa do Mundo de 1970: "[...] meu governo se esforçou em que trouxéssemos o México em cores para a plateia de todos os lares do Brasil [...]" (A GAZETA ESPORTIVA, 1970, p. 16 apud CHAIM, 2014, p. 71).

No caso piauiense, a sobrevivência desses múltiplos sentimentos e sensações experimentados durante a inauguração do estádio também se apresentam no presente, pois as angústias, os clamores, as alegrias e comemorações, mesmo ocorrendo apenas em forma de resíduos, reapresentam-se e se misturam nas narrativas hodiernas. Isso remete ao que Michael Pollak defende em seu texto Memória, Esquecimento, Silêncio, acerca do papel da memória na construção da história, informando que "o presente colore o passado" (POLLAK, 1989, p. 8), sendo importante notar que em alguns casos o presente também pode desbotar o passado, minimizando dores e sofrimentos, como é o caso da tragédia que, na leitura e na releitura do governo da época, não poderia suplantar nem diminuir a grandeza do evento contemplado naquela oportunidade. Essa tragédia parece ter sido um dos pontos descolorantes do passado no presente, haja vista que quase sempre é omitida essa tragédia nas referências sobre a inauguração do estádio, o mesmo não ocorre em relação à euforia provocada por esse evento, que ainda é muito reivindicado no presente como exemplo do entusiasmo vivido no Estado naquele momento.

Corrobora essa análise o fato de que no mesmo relato em que Alberto Silva fala do sofrimento gerado pela tragédia ocorrida no estádio, diz também do delírio gerado pelo fato de um time local ter empatado com o campeão carioca da época, resultado esse conquistado após a tragédia, difundindo a ideia de que a expectativa gerada em torno da implantação do estádio gerou maior euforia que a comoção derivada do acidente ocorrido em seu seio. A resposta do presidente da Confederação Brasileira de Desportos (CBD), João Havelange, à pergunta do então governador contribui muito para esse entendimento. Ao responder "Toca o jogo", quando perguntado pelo então governador sobre as providências a serem tomadas após o acidente de tais proporções, que deixou como resultado vários mortos, revela as prioridades atribuídas pelos promotores dessa solenidade na ocasião.

Não queriam que a prática do futebol perdesse seu prestígio social, nem tampouco que a imagem de um Piauí próspero, em franca via de desenvolvimento, fosse desbotada por esse acidente. Afinal, os anseios por esse estádio já integravam os discursos oficiais desde a chegada de Silva à liderança do Poder Executivo Estadual. O estádio de futebol era mais um dos símbolos da prosperidade, pois junto a ele outros elementos da modernidade poderiam ganhar visibilidade pública, como a eletricidade.

\section{O time Tiradentes: muito além de disputas futebolísticas}

Além disso, o time do Tiradentes funcionou como um bálsamo consolidador da autoestima piauiense ou, mais especificamente, teresinense, como destaca o relato do ex-governador do Estado: 
$\mathrm{Na}$ quarta-feira seguinte, o jogo noturno, a iluminação do estádio era uma das melhores do país, eu sempre faço, se é pouco deve ser bom e ser o melhor e pelo menor preço. Eu trouxe a Philips pra cá, e os refletores desse estádio foram todos ajustados de maneira que não dessem sombra, e aí veio o Cruzeiro, com Tostão, com aquele time todinho do tri, e nesse dia foi outro delírio, porque empatamos de novo, com o Cruzeiro. E aí o terceiro jogo foi em Porto Alegre, campeonato brasileiro, o Tiradentes jogou em Porto Alegre, e venceu o Internacional, aí o povo dançou no meio da rua, então estava consolidada a autoestima piauiense, dos teresinenses (SILVA, 2006, s./p.).

Não é sem propósito que o time do Tiradentes era encarado pelos opositores de Alberto Silva como um obstáculo ao projeto de apagar da memória social do Piauí a imagem do ex-governador, haja vista o forte enlace existente entre o time e o político, amplamente registrado em fotografias oficiais a pedido do próprio governo, como as que seguem, encontradas no Arquivo Público do Piauí, na pasta referente aos documentos oficiais do primeiro mandato albertista:

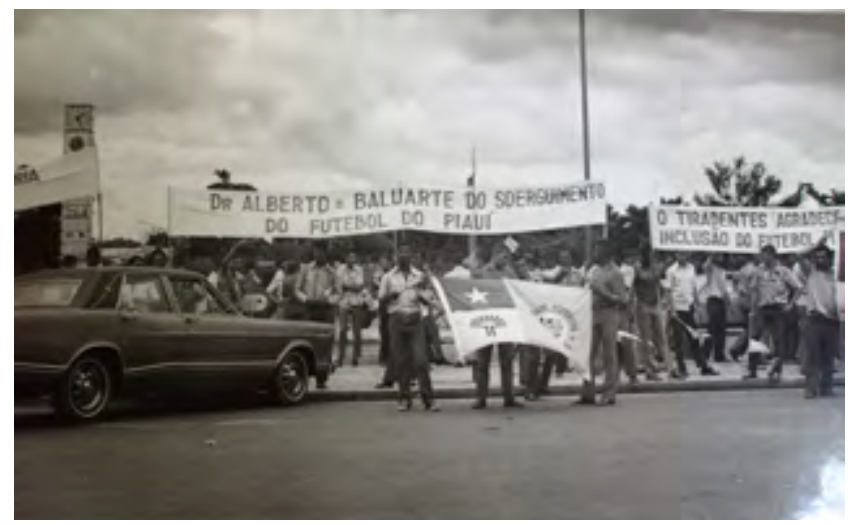

Foto 3. Comemoração pela inclusão do time do Tiradentes no Campeonato Brasileiro. 1973.

(Fonte: Arquivo Público do Estado do Piauí - Casa Anísio Brito)

As mensagens de agradecimento à inclusão do time do Tiradentes no campeonato brasileiro são tratadas secundariamente na fotografia. Em primeiro plano aparece o agradecimento ao governador, "Dr. Alberto: baluarte do soerguimento do futebol do Piauí", tratado como o responsável pelas conquistas nesse âmbito, em mais uma demonstração da publicidade realizada em seu entorno, promovendo mais a ele que ao time em questão, relegado na fotografia ao segundo plano e ainda assim em um ângulo desfavorável e de maneira incompleta. Isso é confirmado pelas faixas que aparecem em uma segunda fotografia produzidas na mesma ocasião, em que aparecem duas frases "Piauí no Brasileirão: primeiro fruto do Albertão" e "O Tiradentes do Sr. Governador [...]". A foto em questão aparece a seguir:

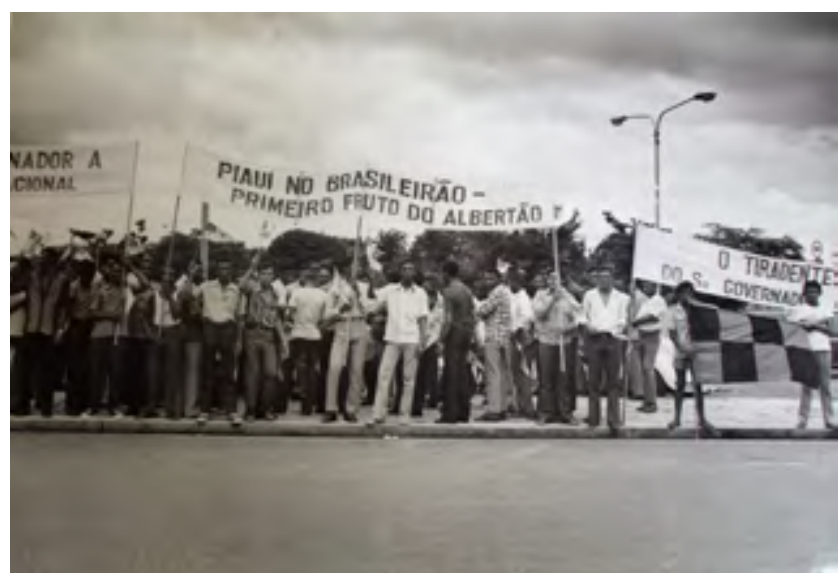

Foto 4. Comemoração pela inclusão do time do Tiradentes no Campeonato Brasileiro. 1973.

(Fonte: Arquivo Público do Estado do Piauí - Casa Anísio Brito)

Embora a fotografia não traga a segunda frase na íntegra, ela permite enxergar a associação feita entre o nome do time de futebol e o líder do Executivo Estadual, em franca alusão à aproximação existente entre ambos, explicando, talvez, por que esse time era tratado como resíduo do prestígio de Silva no cenário piauiense, mesmo após o fim de seu mandato. Por isso mesmo, visto como alvo de combate entre os oponentes desse político. Já a frase central exposta na fotografia relaciona diretamente a inclusão de um time local no principal campeonato de futebol do país à inauguração do estádio de futebol. Mais que isso, ao dizer que a inserção desse time é o "primeiro fruto do Albertão" faz alusão tanto ao estádio quanto ao seu construtor. É oportuno lembrar ainda que ambas as fotografias não são destituídas de um contexto, pois retratam cartazes promocionais produzidos por simpatizantes do governo, haja vista que na primeira (Foto 3) aparece uma bandeira em que o símbolo dessa administração é posto em evidência, sugerindo que havia a participação de pessoas ligadas ao governo na realização dessa manifestação pública.

Promover essas considerações em nada compromete a importância dessa imagem fotográfica para o entendimento da circunscrição histórica em que ela foi produzida, uma vez que essa modalidade de fonte traz consigo uma característica de conjugação de realidade e ficção, atuando como um elemento comemorativo de 
atos públicos e de lideranças políticas, que pretendem publicar as situações retratadas e conservá-las através do tempo. Durante os anos 1970, as imagens do governador, de seus auxiliares ou das lideranças dos governos militares, eram presença constante nos periódicos locais, em explícita demonstração de autopromoção de suas realizações por meio de signos imagéticos. A difusão de seu nome ou de sua imagem é confirmada nos diferentes veículos midiáticos do período, o que contribuiu significativamente para inscrevê-lo entre os agentes históricos a gozarem de reconhecimento e admiração pública.

\section{Considerações finais}

No Piauí, a vibração em torno das conquistas futebolísticas era tanta que passou a permear as discussões a respeito da popularidade ou não de Silva. Passou a ser comum mensurar sua popularidade pela recepção dada a ele nos estádios de futebol, principalmente no Albertão. O acolhimento feito a ele nesse estádio passou a funcionar como o parâmetro de seu prestígio na capital. Em um discurso pronunciado no Senado Federal, na sessão de $1 \stackrel{0}{0}$ de abril de 1981, no qual ele denunciava as perseguições que vinha sofrendo do governador Lucídio Portella, que, segundo ele, criava mecanismos para censurar seu nome junto à imprensa, destaca o prestígio gozado junto à população do Piauí, enunciando a crença de ser o único governante do Piauí, na condição de governador ou ocupando qualquer outro cargo, a entrar no estádio e ser ovacionado de pé por um público de 40 mil pessoas, confirmando a convicção que tinha na época de sua popularidade (SILVA, 1981b, p.5).

Relatos como esse revelam um forte grau de disputas existentes no cenário estadual no período analisado, mas revelam também o posicionamento de alguém que fazia questão de pronunciar a aprovação que recebia da população de seu Estado. Isso pode ser questionado, pois é muito provável que se diga que esse relato tenha sido produzido e publicado pela parte interessada em divulgar sua versão dos fatos, fragilizando o argumento de que os elementos associados ao futebol no Piauí representavam muito da presença do ex-governador na memória piauiense. Mas essa aprovação é confirmada nas narrativas escritas por seus opositores, a exemplo do que ocorreu nos textos de José Lopes dos Santos que, ao se referir às dificuldades enfrentadas por Alberto Silva em seu segundo mandato, menciona o fato de o ex-governador ter-se habituado a ser aplaudido no templo do futebol piauiense, reconhecendo ser o Albertão uma das principais marcas das realizações albertistas em seu governo. Segundo Santos, no final da década de 1980, durante seu segundo governo,

[...] também não mais se repetiram no Estádio Albertão os retumbantes aplausos que o Governador estava habituado a receber quando ali comparecia. Ao contrário, houve apuros na abertura de um torneio de futebol em que o ponta-pé (governamental) inicial não chegou a ser dado (SANTOS, 1989, p. 17).

A aprovação ou reprovação às decisões tomadas por Alberto Silva durante suas administrações passaram a ser mensuradas pelas solenidades promovidas no estádio Albertão, confirmando a tese de que este estádio, mais do que palco do futebol piauiense, funcionava como um templo da memória de seu idealizador, atraindo aplausos dos seus aliados e rejeição de seus oponentes, mas acima de tudo, atuando como uma insígnia do governo albertista e de sua presença na história do Estado.

Se, como advertiu Ítalo Calvino ao falar sobre suas cidades invisiveis, as insígnias, assim como a forma $\mathrm{e}$ o lugar ocupado por um edifício, "bastam para indicar sua função" (CALVINO, 1990, p. 17-18), o estádio Albertão em si já representava essa insígnia marcante da presença de Silva na sociedade piauiense, pois atendia a essas exigências. No entanto, se não fosse suficiente apenas preencher os requisitos destacados pelo escritor italiano, a própria denominação do estádio já promoveria tal feito, e, considerando que as palavras são as mediadoras entre os humanos e seu mundo, inscrever-se na história por meio delas é promover um mecanismo de duração que enfrenta a ferocidade e o desgaste do tempo, transformando-o de adversário em aliado. Este é um dos motivos pelo qual a construção desse estádio gerou tantos conflitos entre os correligionários políticos que disputavam o controle administrativo do Piauí na década de 1970.

\section{Referências}

AGOSTINHO, Gilberto. Vencer ou morrer: futebol, geopolítica e identidade nacional. Rio de Janeiro: Mauad Editora, 2002.

AGOSTINHO, Santo. Confissões. Tradução de J. Oliveira Santos; A. Ambrósio de Pina. São Paulo: Nova Cultural. 1996.

ANSART, Pierre. História e Memória dos Ressentimentos. In: BRESCIANI, Stella; NAXARA, Márcia. Memória e (res)sentimento: indagações sobre uma questão sensível. Campinas, São Paulo: Editora da Unicamp, 2001. 
BORGES, Maria Eliza Linhares. História \& Fotografia. 2. ed. Belo Horizonte: Autêntica, 2008.

CALDAS, Waldnyr. Aspectos sociopolíticos do futebol brasileiro. Revista USP, São Paulo, n. 22, jun.-ago. 1994. Disponível em: http://www.usp.br/revistausp/22/06. Acesso em: 11 nov. 2009.

CALVINO, Ítalo. As cidades invisiveis. Tradução de Diogo Mainard. São Paulo: Companhia das Letras, 1990.

CERTEAU, Michel de. A invenção do cotidiano: artes de fazer. Petrópolis. Rio de Janeiro: Vozes, 2004.

CHAIM, Aníbal Renan Martinot. A bola e o chumbo: futebol e política nos anos de chumbo da Ditadura Brasileira. Dissertação (Mestrado em Ciência Política) - Universidade de São Paulo, São Paulo, 2014.

DELEUZE, Gilles. Proust e os signos. Tradução de Antonio Piquet e Roberto Machado. 2. ed. Rio de Janeiro: Forense Universitária, 2006.

FRANCO Jr., Hilário. A dança dos deuses: futebol, sociedade, cultura. São Paulo: Companhia das Letras, 2007.

KOSSOY, Boris. Fotografia \& História. 2. ed. São Paulo: Ateliê Editorial, 2001.

LYNCH, Kevin. A imagem da cidade. São Paulo: Martins Fontes, 1999.

MÁXIMO, João. A memória do futebol brasileiro. Revista Estudos Avançados - USP, São Paulo, v. 13, n. 37, set.-dez. 1999.

NORA, Pierre. Pierre Nora e o ofício do historiador: "A França doente de sua memória". Entrevista concedida a Jacques Buob et Alain Frachon. Le Monde 2. Hors Série. Colunies. Um dêbat français. Mai-juin 2006.

POLLAK, Michael. Memória, Esquecimento, Silêncio. Estudos Históricos, Rio de Janeiro, v. 2, n. 3, 1989.

RÉMOND, René (Org.). Por uma história política. Rio de Janeiro: Editora UFRJ, 1996.

RIBEIRO, Luiz Carlos. Brasil: futebol e identidade nacional. Efdeportes, Buenos Aires, ano 8, n. 56, enero 2003. Disponível em: http://efdeportes.com/RevistaDigital. Acesso em: 15 out. 2009.

RICEUR, Paul. A memória, a história, o esquecimento. Campinas, SP: Editora UNICAMP. 2007.

SANTOS, José Lopes dos. Dirceu Arcoverde: missão cumprida. 2. ed. Brasília: Centro Gráfico do Senado Federal. 1982.

Piauí: a força do poder municipal. Teresina: Gráfica Mendes. 1989. Vol. I, II e III.
SARMENTO, Carlos Eduardo. A construção da Nação Canarinho: uma história institucional da seleção brasileira de futebol, 19141970. Rio de Janeiro: Editora FGV, 2013.

. A regra do jogo: uma história institucional da $\mathrm{CBF}$. Coordenação Adelina Maria Novaes Cruz, Carlos Eduardo Sarmento e Juliana Lage Rodrigues; Texto Carlos Eduardo Sarmento. Rio de Janeiro: CPDOC, 2006.

SONTAG, Susan. Ensaios sobre a fotografia. Lisboa: Dom Quixote, 1986.

TAVARES, Zózimo. 100 fatos da história do Piaui no Século XX. 3. ed. Teresina: Halley, 2000.

TEIXEIRA, Tomaz. A outra face da oligarquia do Piauí. Fortaleza: Stylus Comunicação. 1981.

Combate: a esperança de vencer - depoimento. Teresina: [S./n.], 1990.

VEYNE, Paul. Como se escreve a história e Foucault revoluciona a história. 4. ed. Brasília: Editora da UNB, 1998.

\section{Fontes:}

A HORA, Teresina, 8 out. 1971.

ARQUIVO PÚBLICO DO ESTADO DO PIAUÍ - Casa Anísio Brito. Fotos 1-4.

FONTINELES, Maria Isaura. Entrevista concedida a Cláudia Cristina da Silva Fontineles. Teresina, 19 out. 2004.

FREITAS NETO, Antonio Francisco de Almendra. Diário do Povo. Teresina, 31 ago. 1997.

O DIA. Teresina, ano XXII, 28 ago. 1973.

MORAES, Genoveva Aguiar. Entrevista concedida a Cláudia Cristina da Silva Fontineles. Teresina, 15 ago. 2008.

SILVA, Alberto Tavares. Entrevista concedida a Cláudia Cristina da Silva Fontineles. Teresina, 03 out. 2006.

Discurso pronunciado no Senado Federal em 10 abril de 1981. In: SILVA, Alberto. Minha Luta por um Piaui melhor. Brasília: Secretaria Especial de Editoração e Publicação do Senado Federal, 1981b. Vol. 5.

\section{Autor/Author:}

CLÁUdia CRISTINA DA Silva Fontineles cfontinelles@gmail.com

- Professora do Programa de Pós-Graduacão em História do Brasil da Universidade Federal do Piauí (UFPI). Doutora em História pela Universidade Federal de Pernambuco (UFPE). Pesquisadora na área de História Política, Memória, Cidade e Ensino de História. Autora de O recinto do elogio e da crítica: maneiras de durar de Alberto Silva na memória e na história do Piauí. (EDUFPI, 2015).

- Professor of the Graduate Program in Brazilian History at the Universidade Federal do Piaui (UFPI). PhD in History from the Universidade Federal de Pernambuco (UFPE). Researcher in the areas of Political History, Memory, City and Teaching of History. Author of O recinto do elogio e da crítica: maneiras de durar de Alberto Silva na memória e na história do Piaui. (EDUFPI, 2015). 